\title{
Correction to: Nanoemulsions as delivery systems for lipophilic nutraceuticals: strategies for improving their formulation, stability, functionality and bioavailability
}

\author{
Seung Jun Choi ${ }^{1,2} \cdot$ David Julian McClements $^{3,4}$
}

(C) The Author(s) 2020

Correction to: Food Sci Biotechnol (2020) 29(2):149-168 https://doi.org/10.1007/s10068-019-00731-4

The article "Nanoemulsions as delivery systems for lipophilic nutraceuticals: strategies for improving their formulation, stability, functionality and bioavailability", written by Seung Jun Choi and David Julian McClements, was originally published Online First without Open Access. After publication in volume 29 issue 2, page 149-168 the author decided to opt for Open Choice and to make the article an Open Access publication. Therefore, the copyright of the article has been changed to (c) The Author(s) 2020 and the article is forthwith distributed under the terms of the Creative Commons Attribution 4.0 International License (http://creativecommons.org/licen ses/by/4.0/), which permits use, duplication, adaptation, distribution and reproduction in any medium or format, as

The original article can be found online at https:// doi.org/10.1007/s10068-019-00731-4.

David Julian McClements

mcclements@foodsci.umass.edu

1 Department of Food Science and Technology, Seoul National University of Science and Technology, Seoul 01811, Republic of Korea

2 Departement of Interdisciplinary Bio IT Materials, Seoul National University of Science andTechnology, Seoul 01811, Republic of Korea

3 Department of Food Science, University of Massachusetts, Amherst, MA 01003, USA

4 Department of Food Science and Bioengineering, Zhejiang Gongshang University, Hangzhou 310018, Zhejiang, China long as you give appropriate credit to the original author(s) and the source, provide a link to the Creative Commons license, and indicate if changes were made.

The original article has been corrected.

Open Access This article is licensed under a Creative Commons Attribution 4.0 International License, which permits use, sharing, adaptation, distribution and reproduction in any medium or format, as long as you give appropriate credit to the original author(s) and the source, provide a link to the Creative Commons licence, and indicate if changes were made. The images or other third party material in this article are included in the article's Creative Commons licence, unless indicated otherwise in a credit line to the material. If material is not included in the article's Creative Commons licence and your intended use is not permitted by statutory regulation or exceeds the permitted use, you will need to obtain permission directly from the copyright holder. To view a copy of this licence, visit http://creativecommons. org/licenses/by/4.0/.

Publisher's Note Springer Nature remains neutral with regard to jurisdictional claims in published maps and institutional affiliations. 